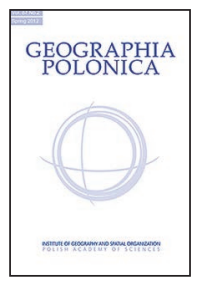

\title{
HISTORICAL HERALDIC SYMBOLS AS A MARKER OF REPRODUCING AND TRANSFORMING REGIONAL IDENTITY: THE CASE OF UKRAINE
}

\author{
Oleksiy Gnatiuk ${ }^{1}$ (D) - Anatoliy Melnychuk ${ }^{2}$ \\ Taras Shevchenko National University of Kyiv \\ Volodymyrska Street 64/13, 01601, Kyiv: Ukraine \\ e-mails: ${ }^{1}$ alexgnat22@ukr.net (corresponding author)・2melnychuk@knu.ua
}

\begin{abstract}
This paper demonstrates a way to examine the transformation of the territorial shape of the region. The official symbols (flags and emblems) of modern administrative units of Ukraine were analyzed for the usage of heraldic symbols of historical regions that lost their administrative status a century before. The results confirm more or less constant symbolic reproduction of historical regions, but their spatial shapes has changed under the influence of new administrative boundaries. Simultaneously, in certain cases historical heraldry loses its former meaning and is involved into the development and strengthening of identities with new administrative regions rather than historical ones.
\end{abstract}

\section{Key words}

transformation of the identity of a region $\cdot$ territorial shape of the region $\cdot$ heraldic symbols $\boldsymbol{~ h i s t o r i c a l ~}$ regions - administrative reform - Ukraine

\section{Introduction}

A system of administrative regions (principalities, voivodeships, viceroyalties and governorates), which roughly reflected physiographic, ethnographic, and economic spatial differences, existed on the territory of modern Ukraine during the 15th-16th centuries under different political regimes. Although the boundaries, and sometimes the administrative centres of these regions have been repeatedly adjusted and changed, in general they were relatively stable entities. This administrative system was finally abolished in the 1930s, when former large regions were split into the smaller first-order administrative units, called oblasts.

However, former administrative regions (now widely known in Ukraine as historical, historical-geographical, or ethnographic regions) continue to exist in the people's minds and are constantly reproduced in symbols and institutions. Their names are reflected in the names of enterprises and companies 
(Gnatiuk, 2014; Gnatiuk \& Melnychuk, 2019), settlements and neighbourhoods, brands and trademarks, beauty contests and universities, media and sports clubs, political parties and NGOs (Homanyuk, 2016, 2017, 2019, 2020). They continue to live in national geographical and historical education and are revitalized in the schemes of economic and socio-geographical regionalization (Gnatiuk \& Melnychuk, 2019). They are used like attractions for tourists, or like weapons by political actors in their races, and their heraldic symbols adorn modern emblems and flags of territorial communities. It seems that the key reason for such popularity of historical regions is the possibility of belonging to something ancient, eternal and apparently something more than just an administrative oblast. A name, appealing to the historical region, seems to increase the importance of the denotation, bring it to the interregional level, and also artificially make it older (Homanyuk, 2017).

However, this informal 'afterlife' of historical regions does not mean that they constantly remain the same as it was a century before, in particular regarding their territorial shape. The results of previous researches testified the change of perceived boundaries of several Ukrainian historical regions: they are markedly adapting to modern administrative boundaries (Gnatiuk \& Melnychuk, 2019) or in some other way interfere with them (Homanyuk, 2016, 2017, 2019, 2020). Similar processes of transformation of territorial shape under the influence of administrative reform were identified and described in Czechia (Šerý \& Šimáček, 2012; Vaishar \& Zapletalová, 2016; Marek, 2020b).

The issue of regional boundaries is important because shaping of boundaries is considered to be an important part of region institutionalisation process (Paasi, 1986, 1991). Moreover, border can also be seen as an important constituent in the process of identifying communities in general (Paasi, 2002). This article deals with the changes in territorial shape of historical regions investigating the contemporary use of historical heraldic symbols. The research is focused primarily on cognitive dimension of a regional identity, 'identity of region', although it is strongly interconnected with the affective dimension of a regional identity, 'regional consciousness of people' (e.g., Paasi, 1986: 132; Paasi, 2002: 139), although these aspects of regional identity are closely interconnected and the described spatial patterns of the identities of informal historical regions can be compared with the spatial patterns of peoples identifications with the same set of regions.

The research questions are following:

1. Whether and how the heraldic symbols of historical regions, being among crucial elements of their identities, are reproduced in contemporary territorial symbols?

2. In which way modern administrative system influences the understanding, reproduction and transformation of the territorial shapes of the informal historical regions?

3. How the use of historical heraldic symbols for institutionalization of modern regions correlates with other markers of identity of a region like toponyms, as well as actual people's regional consciousness?

In this way, the following goals are pursued: (1) to demonstrate the usability of regional heraldic symbols in the study of transformation of identity of region, in particular its territorial shape,(2) to compare the results with previous findings obtained with the use of other methods - direct survey focusing at people's regional consciousness (Melnychuk \& Gnatiuk, 2018) and such markers of identity of a region as toponyms (ergonyms) (Gnatiuk \& Melnychuk, 2019), and (3) contribute to a better understanding of the truly intricate concept of region, in particular the processes of its formation, reproduction, transformation, and disappearance (Semian, 2016; Zimmerbauer et al., 2017; Marek, 2020b). These research questions will be examined using the example of the several historical regions of the Right-Bank Ukraine. 


\section{Theoretical and methodological background}

New regional geography considers regions as spatial structures (Giddens, 1984), historically contingent dynamic processes (Pred, 1984) and social constructs (Cresswell, 2013) that exist only if they are in people's consciousness (Zimmerbauer, 2011, Marek, 2020a) and depend on people and their communications (Neumann, 1994). Thus, the concept of region as a social construct involves an enormous influence of the cultural, historical and geographical context which plays a cardinal role in the formation of regions (Graham, 2000; Kasala \& Šifta, 2017). According to the institutionalisation of region theory (Paasi, 1986, 1991, 2001, 2002, 2009, 2011; Paasi \& Metzger, 2017), identity of a region emerges due to boundaries, symbols, and institutions, being key features of every region. In this way, region is not static, but constantly becoming (Pred, 1984): once established, it is continually reproduced, gradually transformed in individual and institutional practices, and may disappear (Marek, 2020b).

Although administrative regions may be gradually transforming in terms of symbols and institutions, they usually keep their territorial shape and are typically perceived on the basis of their official boundaries (Marek, 2020b). Such stability of borders complicates the study of regions as dynamic formations, creating the illusion of their certainty and inalterability. Not surprisingly, administrative reforms (amalgamation, splitting, or total liquidation of administrative regions) are considered as important factor influencing both transformation of the identity of the region and regional consciousness of population, as they affect a wide range of key regional features, including boundaries, institutions and symbols (Paasi, 2009, 2011; Raagmaa, 2002; Zimmerbauer et al., 2012; Zimmerbauer \& Paasi, 2013). In particular, regions that have lost administrative/de jure status, or have never had such a status, are of special interest for researchers focus- ing at the processes of emergence, evolution and disappearance of regions, as their perceived boundaries became flexible. As Marek (2020b) points out, "focusing on regions without official status can help to reveal how and why people construct their perceptual regions, and how and why these subjective images develop over time".

Relict (or phantom) boundaries remain political and cultural barriers visible in different forms of contemporary economic, social and political activity and can be used in the construction or reanimation of territorial identities (Kolosov \& Więckowski, 2018). In particular, they may reveal themselves in such phenomena as election behaviour; among the brightest CEE examples may be electoral patterns in Poland, Romania and Ukraine (Kowalski, 1999; Zarycki 1999, 2015; Kowalski, 2019; Dobysh \& Yatsenko, 2020). As Kowalski puts it "the term relict border can be assigned, not only to cultural frontiers, but also to all informal boundaries that represent the heritage of an old political (and administrative) system" (Kowalski, 2020). There is evidence from different national contexts that identities of historical (informal) regions, as well as regional consciousness of population, are saved in people's minds for long time intervals (Chromý, Kučerová, \& Kučera, 2009; Vukosav, 2011; Šerý \& Šimáček, 2012; Vaishar \& Zapletalová, 2016; Vukosav \& Fuerst-Bjelišs, 2016; Melnychuk \& Gnatiuk, 2018; Marek, 2020b), and may be quickly re-established under the favourable circumstances (Raagmaa, 2002). In this sense, the evolutionary continuity of a society is very important: if the continuity of regional communities is preserved, the continuity of the relationship of belonging is usually maintained (Šerý, 2014).

However, perceived boundaries of such regions may significantly transform under the influence of the new administrative system or other factors. The selective spatial shift of phantom borders was revealed in Poland (Jańczak, 2015). Although the perceptual cores of traditional historical regions are quite stable in the collective memory 
and are clearly defined, at least certain parts of their borders are unclear and fuzzy, often converging with modern administrative boundaries, which often ignore old (historical) boundaries (Šerý \& Šimáček, 2012; Vaishar \& Zapletalová, 2016; Nowak, 2018; Marek, 2020b). In this way, the territorial shapes of old historical regions are transformed, while certain newly emerged administrative regions may strengthen their identity due to the most eroded consciousness concerning these historical regions and their boundaries (Gnatiuk \& Melnychuk, 2019; Marek, 2020b). According to Marek (2020b), the more radical the administrative changes (in terms of toponyms and boundary mismatches), the fuzzier the collective perceptions of historical boundaries become, as well as peoples' consciousness of historical regions. In some cases, initially integral perceptual region may split into two or more regions, and the initial perceptual core may also change, as it happened with Taurida/Tavria region in the Southern Ukraine (Homanyuk, 2016, 2017, 2019, 2020). Moreover, homonymous regions determined for various purposes may mutually spatially overlap or supplement each other (Semian, 2012). Boundaries of different scales are intrinsic element of territorial identity; however, they "are not fixed lines in space but their allocation, delimitation and demarcation, their regime and functions strongly depend on their interpretation by the people, their symbolic role" (Kolosov \& Więckowski, 2018).

In view of this, as was shown by Gnatiuk and Melnychuk (2019) on the Ukrainian case, modern administrative regions may be classified as 'anchor' (which grasp the identity of a particular historical region, while identities of other historical regions are gradually disappearing), and 'swing' (where identities of several historic regions continue to coexist and/or principally new identity of a region is emerging). In the case of Czechia, there are certain 'schizophrenic regions' as well, where identities of both Bohemia and Moravia are essentially reproduced and perceived to the present-day (Chromý, 2003;
Marek, 2015). It was supposed that likelihood of these scenarios is influenced by factors like (1) initial predominance of identity of one historical region within the modern administrative region, (2) location of modern regional capital (central city) within the limits of initially dominating historic region, and (3) semantic link between the name of modern administrative region or its central city and the name of historical region (Gnatiuk \& Melnychuk, 2019). Transformation of perceived regional boundaries may be driven also by naming and renaming of the settlements, state and municipal entities, media, public education, mass events, certain (geo)political projects, as well as by commodification of a regional toponym at the market of goods and services (Vukosav \& Fuerst-Bjeliš, 2016; Homanyuk, 2016, 2017, 2019, 2020; Gnatiuk \& Melnychuk, 2019; Marek, 2020b).

Transformation of perceived territorial shape (boundaries) may be studied based on (1) directly investigated individual perceptions using Lynch-type mental maps (Lynch, 1960), when respondents are asked to draw their perceptions of a region at the map (Siwek \& Kaňok, 2000; Semian, 2012; Šerý \& Šimáček, 2012; Chalupa, 2015; Marek, 2015; Markeliuk, Gomaniuk, \& Sarkisov, 2019; Marek, 2020b), (2) regional consciousness of population, asking people about their identification with the region, their knowledge on the region and attitudes to the region (Siwek \& Kaňok, 2000; Šerý, 2014; Vaishar \& Zapletalová, 2016; Melnychuk \& Gnatiuk, 2018), and (3) markers of identity of a region - regional features (symbols and institutions) (Więckowski, 2021).

Among the identity markers, attention was paid primarily to toponyms, semantically related to the name of region, as the latter is considered to be the most important regional symbol (Paasi, 1986, 1991; Raagmaa, 2002; Semian, 2012; Simon et al., 2010). Such categories of toponyms like names of businesses, companies, public associations, local action groups and geographically-tied events, containing or reflecting in some way the name of the region, have shown to be 
valuable instruments of delineating the boundaries of vernacular regions (Zelinsky, 1980; Reed et al., 1990; Oliinyk \& Gnatiuk, 2013; Melnychuk et al., 2014; Gnatiuk, 2014; Semian et al., 2016; Vukosav \& Fuerst-Bjeliš, 2016; Gnatiuk \& Melnychuk, 2019). However, other regional symbols, both historical and newly invented, are also suitable for such researches (Paasi, 2001). Graphic symbols play an important role in the process of regional identity formation, institutionalization of region and in region's marketing, they often become key images associated with a region and are widely (although not always in the right way) used by local development actors (Šifta, 2016; Šifta \& Chromý, 2017). A system of regional symbols constitutes an essential part of regional perceptual portrait, and the latter may be used to determine the level of regional social and economic development (Mezentsev \& Mezentseva, 2005). Through graphic symbols, including heraldic elements, historical informal regions continue to live as part of the identity of modern regions, e.g. only a few of contemporary Ukrainian regions have completely new emblems without the use of any ancient symbols of historical regions or cities (Grechylo, 2004). Homanyuk (2016) supposed that the similarity of emblems of the Taurida governorate and the city of Kherson somehow affected the gradual equation of Tavria to the modern Kherson oblast. In Czechia, a close relationship was found between regional product labelling and the formation of regions and their identities (Kašková \& Chromý, 2014). In this way "regional symbols and meanings often bring together the past, present and future of a region" (Paasi \& Zimmerbauer, 2011).

\section{Data, methods, and cases}

In this study, the official symbols (flags and emblems) of modern administrative units of Ukraine (oblasts and districts), which originated basically in 1990-2000s, were analyzed for the usage of heraldic symbols of historical regions.
Hereinafter, we use an original term 'oblast' for the Ukrainian first-level administrative units in order not to confuse them with the other types of regions, e.g. historical, physiographic, etc. However, we use a term 'district' for the second-level administrative units, originally called 'raions', as a more convenient for English-speaking audience. Another remark is that we worked with a system of districts that existed in Ukraine, with certain adjustments, since 1920s until the recent adoption of a new administrative division at this level (Resolution of the Verkhovna Rada of Ukraine No 3650 of 17.07.2020 "On the formation and liquidation of districts").

For better understanding the research results, it is also crucial to know who, when, and why created the heraldic symbols of modern Ukrainian oblasts and districts. During the Soviet era, these administrative units had neither emblems nor flags. In independent Ukraine, the issue of creating modern symbols for administrative units has been repeatedly brought up at the annual scientific conferences of the Ukrainian Heraldic Society (UHS), established in 1990. The Law on Self-Government, adopted in 1997, provided that oblasts and districts may have own coats of arms and flags that should reflect local historical, cultural, socio-economic and other features and traditions, and must be approved by the relevant self government body (oblast or district council). Simultaneously, the UHS developed general recommendations for the creation of a comprehensive system of territorial and municipal emblems and flags, and provided advisory and practical assistance during the creation and approval of local symbols. In most cases, a district or oblast council announced a competition, open for participation of local community members, including ethnographers, activists, artists, and professional heraldry specialists (Grechylo, 2004). However, the absolute majority of territorial community has never been involved into the process of creation of local territorial symbols. Furthermore, very often approved territorial symbols were elaborated by the UHS experts who had high 
professional skills but no direct relationship to the particular oblast or district. Typically, the authors of heraldry of districts have been advised by the UHS to take into account the oblast symbols (if already approved), and this could contribute to the uniformity of district heraldry in some oblasts. To summarise, creation of the modern territorial symbols in modern Ukraine was rather top-down than down-top process, although a lot of realized and approved ideas had local origin. This mean that modern heraldry of oblasts and districts reflects more the identity of the region constructed 'from above' than the regional consciousness of local population, while the latter is better reflected, e.g., by the names of private enterprises (cf. Gnatiuk \& Melnychuk, 2019).

Descriptions of the historical and contemporary territorial Ukrainian heraldic symbols were taken from the scientific works by Andrii Grechylo, the President of Ukrainian Heraldry Society (Grechylo, 2000, 2004, 2008, 2010), the edition "Ukraine: coats of arms and flags" (Kysliak \& Neskoromnyi, 2010), and the website of the Ukrainian Heraldry Society (UHS, 2020).

Attention was focused on five historical regions of the Right Bank Ukraine: Podolia, Bratslavschyna (Bratslav region), Volhynia, Galicia (Halychyna) and Kyivschyna (Kyiv region). These regions were chosen for the analysis due to large territory coverage, sufficiently clear evolution of their administrative structures together with corresponding historical heraldry, and the presence in contemporary public discourse in Ukraine. E.g. we did not consider the former Belz voivodeship and its heraldry due to small size of its territory and almost total absence of this historical region in the national media space beyond the narrow-focused scientific literature. The following is a brief and somewhat simplified description of (1) political and administrative development of these regions and (2) key elements of their heraldry. Typical examples of the described historical heraldic symbols, as well as examples of their use in modern territorial emblems, are shown at Figure 1.
The relict boundaries of historical administrative regions, overlapped with the modern administrative division (until 17.07.2020) are present at Figure 2.

Podolia and Bratslavschyna. Podolia as a separate principality is known since 1340s. In 1434, Podolian voivodeship of the Kingdom of Poland was established within the Western Podolia, while the Eastern Podolia remained under the rule of the Grand Duchy of Lithuania until 1566, when it was separated as a Bratslavian voivodeship. Since 1569, both voivodeships became administrative units of the Polish-Lithuanian Commonwealth. After the second partition of Polish-Lithuanian Commonwealth (1793), both voivodeships were transformed into the eponymous viceroyalties of the Russian Empire, and in 1796 these viceroyalties were merged into single Podolian governorate finally liquidated in 1925.

The golden face of the sun constantly was the central element of the historical Podolian heraldry. Its first written mention dates back to the Battle of Grunwald, when the flag of Podolian regiment was described as the image of the golden face of the sun on the red field. Subsequent descriptions and drawings depicted the emblem of Podolian voivodeship like a golden face of the sun on a white field. The emblems of Podolian viceroyalty and Podolian governorate retained "the golden sun with a face and sixteen rays" as the main element, but the white field was replaced with a blue one, as conventional heraldic norms prohibited placing metal figures on a metal field. The emblem of Bratslavian voivodeship looked like a silver cross with a blue shield with a silver crescent in the centre. The emblem of Bratslavian viceroyalty had a completely different appearance - a golden castle with towers on a red field.

Volhynia. In the middle of the 10th century, Volhynian land became part of Kyivan Rus, and in the end of the 1150s it was transformed into the Volhynian principality. Volhynian voivodeship was established in 1566 as a part of the Grand Duchy of Lithuania, to be part of the Polish-Lithuanian 


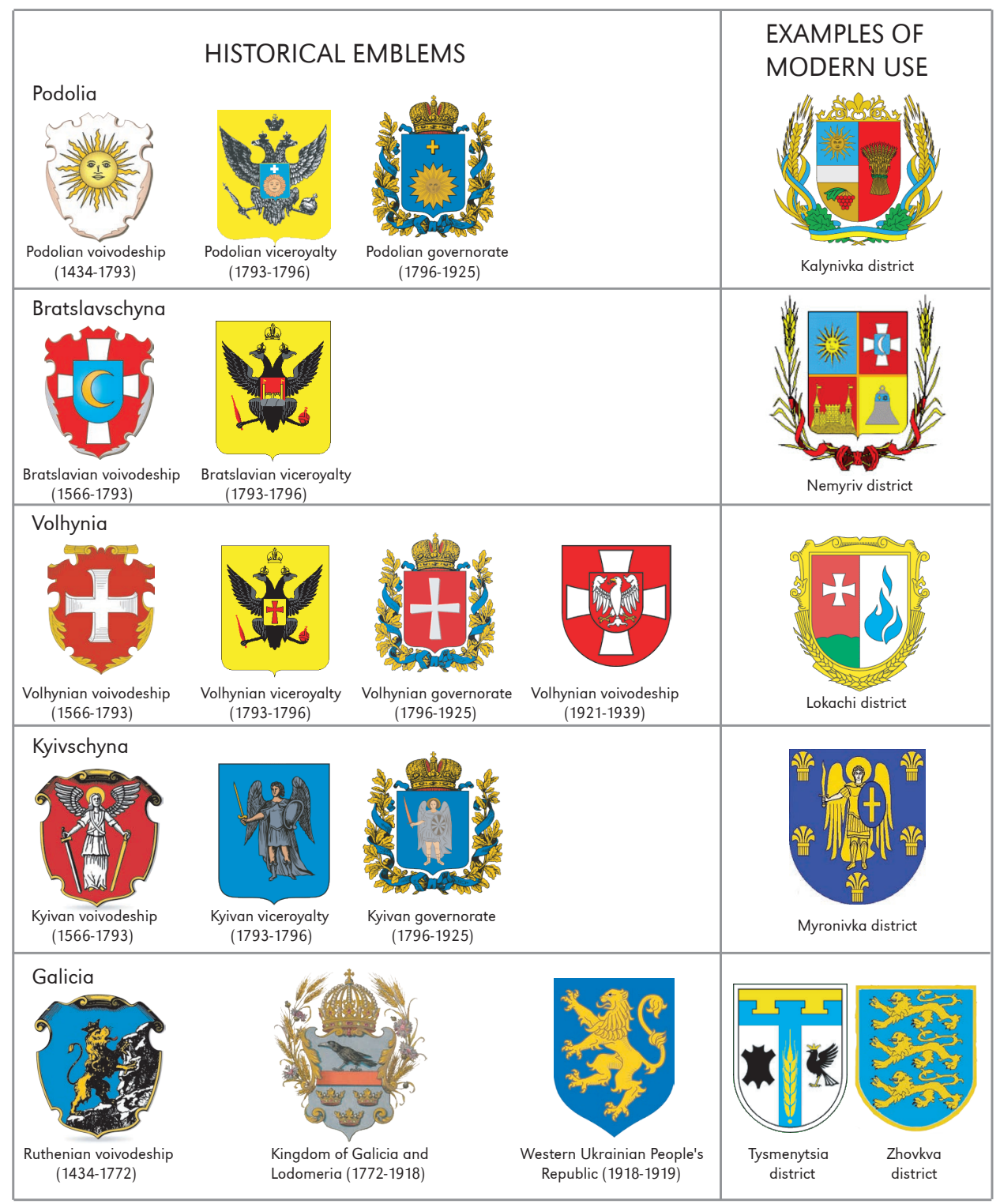

Figure 1. Examples of heraldic symbols of historical regions and their use in modern territorial emblems Source: authors' compilation based on Grechylo (2010) and Ukrainian Heraldry Society (http://uht.org.ua/en).

Commonwealth in 1569, but as part of the Polish Crown. After the second partition of Poland, the voivodeship was transformed subsequently into the Volhynian viceroyalty (1793) and Volhynian governorate (1795).
In 1921, the western part of the governorate was ceded to Poland and became a territorial core for the re-established Volhynian voivodeship that existed until 1939, while Volhynian governorate was finally liquidated in 1925. 


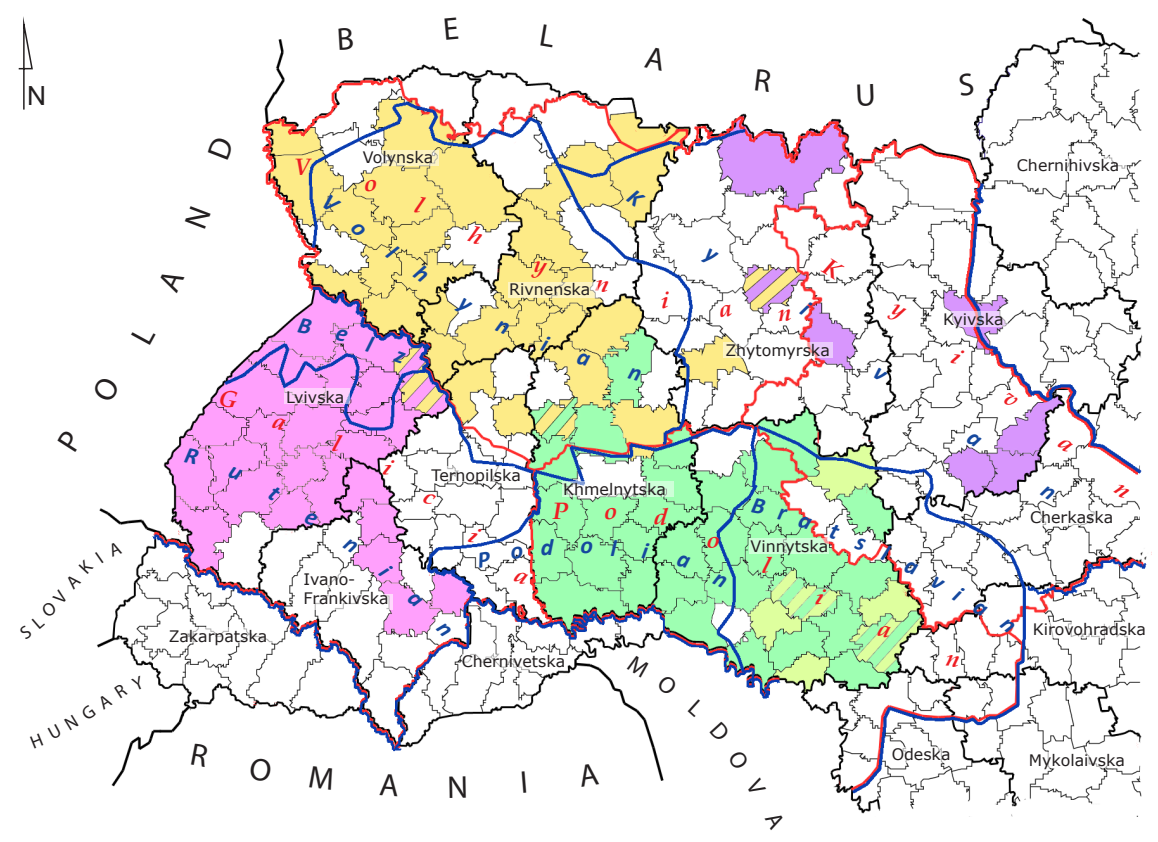

ORIGIN OF HERALDIC ELEMENTS:

LABELS:

BORDERS:

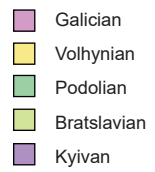

$\begin{array}{ll}\text { Podolian } & \text { voivodeships } \\ \text { Volhynian } & \text { governorates } \\ \text { Ternopilska } & \text { oblasts } \\ \text { POLAND } & \text { countries }\end{array}$

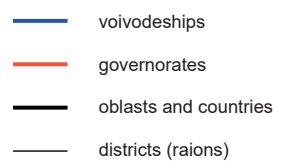

Figure 2. Use of heraldic symbols of historical regions in the emblems and flags of administrative districts Source: authors' analysis; borders of voivodeships and governorates taken from Krykun (1993) and National Atlas of Ukraine (2007).

Traditional heraldic symbol of Volhynia - a silver cross on a red shield - constantly appeared on the emblems of Volhynian territorial units with certain modifications and additions of the Polish and Russian state symbols respectively. The shape of the central heraldic figure, the so-called Volhynian cross, changed over the centuries, while the combination of colours was stable, except for the emblem of Volhynian viceroyalty, where a red cross was depicted on a golden shield.

Kyivschyna. The Kyivan principality was shaped in the middle of the 9th century around the city of Kyiv. Later, in the 10th-12th centuries, it became the political core of Kyivan Rus. After the Mongol invasion, the Kyivan principality joined the Grand Duchy of Lithuania, and in 1471 it was transformed into Kyivan voivodeship as a part of the Grand Duchy of Lithuania and from 1569 as part of the united Polish-Lithuanian Commonwealth. After the transfer of Kyiv to the control of the Moscovy in 1667, the centre of the voivodeship moved to Zhytomyr. On the lands controlled by Russia, first Kyivan governorate was formed in 1708, which in 1781 was divided into Kyiv, Chernihiv, and Novhorod-Siverskyi viceroyalties. In 1796, Kyiv, together with the right-bank lands of Kyivan voivodeship, annexed by the Russian 
Empire, was transformed into the second Kyiv governorate that existed until 1925. Modern Kyivska oblast was formed in 1932, but until 1954 it also encompassed the area of the modern Cherkaska oblast.

In official documents of the Grand Duchy of Lithuania, the emblem of Kyivan principality was depicted a walking bear on a blue or white shield. Under the Polish rule, the regional symbol changed radically to the image of Archangel Michael with a lowered sword. The emblems of Kyiv viceroyalty and Kyivan governorate inherited the figure of the archangel Michael as the main symbol, but in slightly modified form (in silver clothing, with a flaming sword and a silver shield raised).

Galicia. The Galician Principality with a centre in Halych was formed in 1084. In 1199-1203 and 1241-1349 it constituted a part of the united Kingdom of GaliciaVolhynia, and later was absorbed by the neighbouring Kingdom of Poland: Ruthenian voivodeship was established in 1434, and Belz voivodeship in 1462. After the partition of Poland in 1772, the Kingdom of Galicia and Lodomeria was created as a part of AustriaHungary, which existed until 1918, when the Western Ukrainian People's Republic was proclaimed within its eastern part settled predominantly by Ukrainians. In 19201939, the territory of Galicia was under the rule of Second Polish Republic and was divided between Lviv, Stanislav and Ternopil voivodships, which are roughly corresponding to the modern oblasts.

The oldest and most authentic heraldic symbol of Galicia is a jackdaw, which is mentioned since the 11th century and first clearly depicted in the description of the flag of the Galician regiment of the Ruthenian voivodeship in the Battle of Grunwald: "black jackdaw with a crown on head in a white field". In fact, jackdaw ('halka' in Ukrainian) probably gave a name to the city of Halych and thus to the whole region. When the region was included to the Austrian crown, the emblem was changed to three golden crowns. However, as early as 1804 , the black jackdaw reappeared on the coats of arms of Galicia and Lodomeria together with three crowns.

A golden lion can be considered an alternative symbol of Galicia. It is believed that the golden lion on a blue shield was used as the emblem of the Galicia-Volhynia Principality in the 13th century. Later, the golden lion became a symbol of the city of Lviv, Lviv land, and Ruthenian voivodeship. In 1918-1919, the golden lion on a blue shield became the state emblem of the Western Ukrainian People's Republic. Due to the durable role of Lviv as the principal city of Galicia, the golden lion has become, perhaps, the most recognizable regional symbol.

\section{Results}

\section{District-scale symbols}

Historical symbols of Podolia (golden face of sun on a blue field, or just golden face of sun) are present on the flags and emblems of 18 out of 26 districts of Vinnytska oblast (69.2\%) and 14 of 20 districts of Khmelnytska oblast (70.0\%). At the same time, outside these two oblasts, Podolian symbols are never used, including those districts of Ternopilska, Odeska, Cherkaska and Kirovohradska oblasts that previously belonged to the Podolian administrative units (Fig. 2).

There are also internal differences in the use of Podolian heraldic symbols within Vinnytska and Khmelnytska oblasts. In the southern part of Khmelnytska oblast, which belonged to Podolia, Podolian symbols are used in 10 districts out of 11 (90.9\%); the only exception here is Khmelnytskyi district, where symbols are derived from the emblem of the central city. In the northern part of Khmelnytska oblast, which historically belonged to Volhynia, 3 out of 9 districts (33.3\%) use only Podolian symbols, the other 3 districts (33.3\%) use Volhynian symbols, and one district $(11.1 \%)$ uses symbols of both historical regions, the remaining 2 districts do not use heraldic symbols of historical regions.

Vinnytska oblast shows the following patterns of Podolian symbols use: within the territory encompassed by both Podolian 
voivodeship and Podolian governorate in 5 districts out of 6 (83.3\%); within the territory encompassed by the Bratslavian voivodeship and Podolian governorate in 13 districts out of 16 (81.3\%); within the territory encompassed by Bratslavian voivodeship but not by Podolian governorate - in 2 districts out of 5 (40.0\%).

Thus, the key factor defining the use of Podolian heraldic symbols is belonging of the territory to the pair of oblasts, Vinnytska and Khmelnytska, which in contemporary borders together cover most of the historical Podolia. The factor of belonging of the territory to the historical Podolian administrative units acts as secondary and, factually, determines only the internal differentiation of the use of Podolian heraldic symbols within these two oblasts; historical Podolian territories, which nowadays are located outside these two oblasts, do not use Podolian symbols.

The historical symbols of Bratslavschyna are used nowadays exclusively within Vinnytska oblast and exclusively within the former Bratslavian voivodeship. None district of Vinnytska oblast outside the former Bratslavian voivodeship uses Bratslavian symbols and none district of other oblasts that was part of Bratslavian voivodeship uses Bratslavian symbols. Thus, in this case, both factors belonging to the modern region and to the historical region - have equal power.

In general, Bratslavian heraldic symbols are used much less often than Podolian. They are present only in 6 out of 20 districts of Vinnytska oblast that belonged to Bratslavian voivodeship (30.0\%). At the same time, Podolian symbols are used in 14 of these districts (70.0\%), and the other 2 districts use symbols of both Podolia and Bratslavschyna. Even in the territory that was encompassed by Bratslavian voivodeship but not included into Podolian governorate, Podolian symbols are used more often than Bratslavian (2 and 1 district out of 5 , respectively).

The historical symbol of Volhynia (silver cross on a red field, sometimes just a silver cross) is most represented in Volynska (10 out of 15 districts, 66.6\%) and Rivnenska
(11 out of 17 districts, $64.7 \%$ ) oblasts. However, this symbol is also used in other oblasts within the territories that belonged to historical Volhynia: (1) in the north of Khmelnytska oblast - in 4 out of 9 districts that were part of Volhynian voivodeship and/or governorate, (2) in the north of Ternopilska oblast - in 2 out of 5 districts that belonged to Volhynian voivodeship and/ or governorate, (3) in Zhytomyrska oblast in 2 out of 16 districts, covered by Volhynian governorate, (4) in 1 district of Lvivska oblast that was partially covered by Volhynian voivodeship.

Thus, despite the concentration of Volhynian heraldic symbols within Volynska and Rivnenska oblasts, these symbols are distributed outside their borders as well within the territories encompassed by the historical Volhynia. At the same time, districts outside the former Volhynian administrative units, do not use Volhynian symbols. In particular, this consideration refers to a pair of districts in the north of Volynska and Rivnenska oblasts, which were part of Brest voivodeship and successively of Slonim, Lithuanian and Grodno governorates. Thus, in the case of Volhynian symbol, the key factor of its modern use is the affiliation of the territory to the historical Volhynian administrative units, while the affiliation to modern oblasts seems to play a much smaller role. The other interesting fact is that Volhynian symbol is used roughly equally in the modern Rivnenska and Volynska oblasts, while the name of the latter emphasizes its claim to be the successor of historical Volhynia.

It seems that belonging to Volhynian voivodeship is a more influential factor than belonging to Volhynian governorate: Volhynian symbols are now used in $68.3 \%$ of districts that were part of Volhynian voivodeship, in $48.3 \%$ of districts that were part of Volhynian governorate, and in only $26.7 \%$ of districts that belonged to Volhynian governorate, but not to Volhynian voivodeship. But this hypothesis is questioned by the north-eastern corner of Rivnenska oblast and the north-western corner of Volynska oblast, 
which belonged to Volhynian governorate but did not belong to Volhynian voivodeship: here Volhynian symbol is used by at least a half of the districts. However, the essential point to remember is that the Volhynian voivodeship of the Second Polish Republic included the entire present-day Volynska and Rivnenska oblasts. An alternative hypothesis may be the factor of territorial affiliation to Zhytomyrska oblast. Indeed, the spatial continuum of districts that use Volhynian symbol ends just on the western border of Zhytomyrska oblast; in particular, historical Volhynian heraldry is not used in the extreme west of it, which was covered not only by Volhynian governorate, but also by Volhynian voivodeship. In view of this, the use of Volhynian symbol in 2 districts of the Zhytomyrska oblast is an exception to the rule.

Historical symbol of Kyivschyna (Archangel Michael) is used in modern territorial emblems and flags surprisingly rarely. Except for the city of Kyiv, it was found in only 3 out of 26 districts of Kyivska oblast (11.5\%), all in its southern part, and in 3 out of 23 districts of Zhytomyrska oblast (13.0\%). Thus, the use of Kyevan heraldic symbol is not limited to the modern Kyivska oblast, but its occurrence in other regions is unequal. In Zhytomyrska oblast, Kyivan symbols are present even in the part that belonged to the Volhynian governorate (2 districts, one of them uses both Kyivan and Volhynian heraldic symbols), but in Cherkaska oblast, including its rightbank part, which until the middle of the 20th century was under the direct administrative influence of Kyiv, no cases of use of Kyivan symbols were recorded. This is consistent with the heraldry analysis at the oblast scale (see following subsection): Zhytomyrska oblast is positioned as a crossroad of several historical/ethnographic regions, while Cherkaska oblast builds its own identity rather as Shevchenko's and Cossack's land. Within the former Kyivan voivodeship, Kyivan symbols are used by the city of Kyiv and 4 districts ( $8.8 \%$ of the total number), within the former Kyivan governorate - by the city of Kyiv and 6 districts $(9.8 \%$ of the total number). Outside of their limits, the use of Kyivan symbols has not been recorded.

The historical heraldic symbols of Galicia are used exclusively in two oblasts - Lvivska (17 out of 19 districts, $89.5 \%$ ) and IvanoFrankivska (5 out of 14 districts, 35.7\%); exactly these two oblasts are completely located within the boundaries of historical Galicia. However, Galician symbols have become much more widespread in Lvivska oblast, which accounts for $77.3 \%$ of all cases. The reason for this disproportion may be the more flat relief in Lvivska oblast compared to Ivano-Frankivska oblast. As it can be seen from the map, Galician symbols are typical for the lowland parts of both oblasts, while mountainous districts prefer symbols that reflect features of local natural landscapes (relief, flora, or fauna).

The other difference is that two oblasts use different symbols of Galicia: in Lvivska oblast the image of a golden lion is unalterable, while in Ivano-Frankivska oblast 2 districts use the image of a golden lion, 2 other districts use a black jackdaw, and 1 district uses three golden crowns. In summary, the golden lion is present in $86.4 \%$ of cases, the black jackdaw in $9.1 \%$ of cases, the golden crowns in $4.5 \%$ of cases. The most probable explanation for this disproportion is that the golden lion is now perceived not only as a symbol of Galicia, but primarily as a symbol of Lviv and Lvivska oblast, which impedes its use in other 'Galician' oblasts. In turn, a tendency to use the black jackdaw in Ivano-Frankivska oblast may be explained by the origin of this symbol that comes from the ancient emblem of the city of Halych, located nowadays exactly in Ivano-Frankivska oblast.

Heraldic symbols of Galicia are completely absent on the district emblems and flags in Ternopilska oblast, including those districts that belonged to historical Galicia. The only common feature for the district heraldry of Ternopilska oblast and the district heraldry of Ivano-Frankivska and Lvivska oblasts is the widespread use of national Ukrainian colours - blue and yellow. Possible reason for such a situation is similar to the cause of selective 
use of heraldic symbols in Lvivska and IvanoFrankivska oblasts: golden lion and black jackdaw have already been claimed by these two oblasts, while Ternopilska oblast has no own Galician heraldic symbol to use.

\section{Oblast-scale symbols}

The heraldic symbols of several modern Ukrainian oblasts are directly derived from the heraldry of one or more historical regions under analysis (Fig. 3):

- The central figure of the both emblem and flag of Lvivska oblast is a golden (yellow) crowned lion - a historical symbol of the Ruthenian Kingdom, Ruthenian voivodeship and Lviv land, constituting a part of Galicia.
- The emblem and flag of IvanoFrankivska oblast contain the image of another historical symbol of Galicia a black jackdaw in a golden crown with outstretched wings.

- The emblem and flag of Khmelnytska oblast testify to its belonging to the two historical regions: Podolia (golden face of sun, blue field) and Volhynia (red field). It worth noting that Podolian identity is brought to the fore both by the number of symbols (two Podolian and one Volhynian) and by their subordination (the Podolian sun is located in the centre, against the background of both coloured fields).

- The emblem and flag of Vinnytska oblast combine heraldic symbols of two historical regions - Podolia (golden face
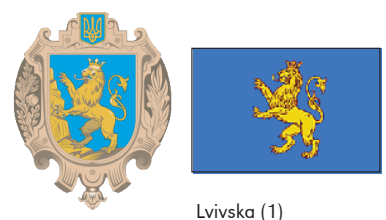

Lvivska (1)
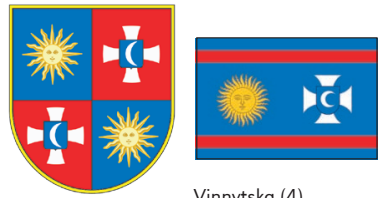

Vinnytska (4)

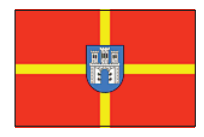

Zhytomyrska (7)
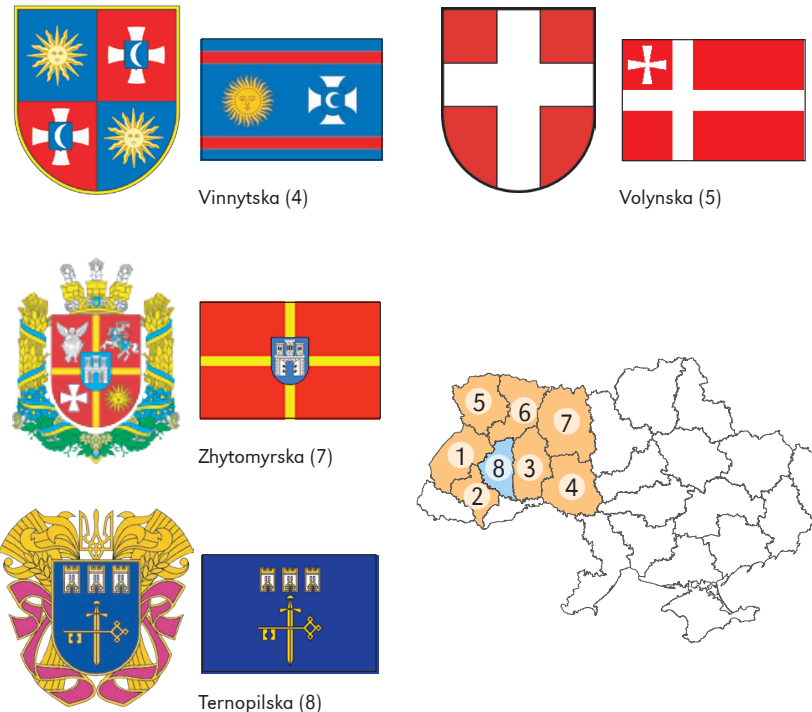

Volynska (5)
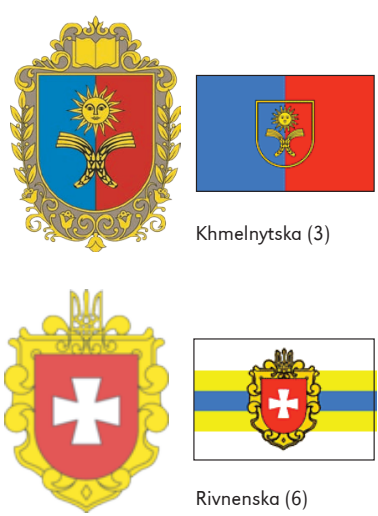

Rivnenska (6)
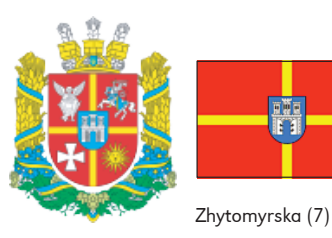

Ternopilska (8)

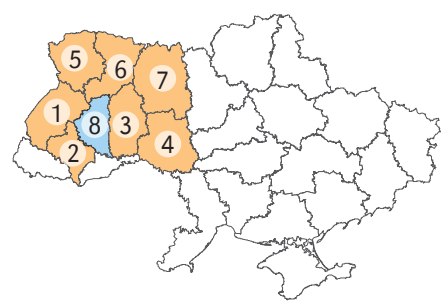

Oblasts with modern symbols derived from heraldry of the historical regions under analysis Oblast with modern symbols referring to the historical regions under analysis

Numbers near the oblast names correspond to the numbers on the map

Figure 3. Use of heraldic symbols of historical regions in the emblems and flags of administrative oblasts

Source: authors' analysis; pictures of emblems and flags based on the web-site of Ukrainian Heraldry Society (http://uht.org.ua/en) and official web-sites of oblast councils. 
of sun on a blue field) and Bratslavschyna (silver cross with a blue shield with a silver crescent).

- The design of the emblem and flag of Volynska oblast derives from the main heraldic symbol of historical Volhynia a silver (white) cross on a red field.

- The same Volhynian symbol - a silver (white) cross on a red field - appears on the emblem and flag of Rivnenska oblast.

- The emblem of Zhytomyrska oblast contains the symbols of four informal regions simultaneously: Kyivschyna is represented by silver Archangel Michael, Volhynia by a silver cross, Podolia - by a golden sun, and Polesia, as a part of the Grand Duchy of Lithuania (although Polesia is not a former administrative region, and thus is not typically considered as a historical region) - by a horseman with a shield (Pahonia, lit. 'Chase'). However, it should be noted that historical Podolia never encompassed, even partially, modern Zhytomyrska oblast, and the interpretation of Pahonia as Polesian emblem is quite disputable issue. The central figure of the emblem, a silver open city gate with three towers on a blue field, comes from the emblem of Zhytomyr. Unlike the emblem, the flag of Zhytomyrska oblast is based exclusively on the emblem of Zhytomyr and does not contain any symbols of historical regions.

- The modern symbols of Ternopilska oblast are not directly connected with the heraldry of the historical regions. However, according to the justification, the three fortress towers on the emblem and flag symbolize not only a large number of castles and fortresses, but also three historical lands, parts of which are included into the contemporary Ternopilska oblast - Galicia, Volhynia and Podolia.

At the same time, emblems and flags of other oblasts do not use the heraldic symbols of the historical regions covered by this research.

\section{Discussion}

The results of the study confirm vitality of informal historical regions and their constant symbolical reproduction just according to the theory of regional institualization (Paasi, 1986). Heraldic graphic symbols, linking the region to a broader historical and geographical context (Paasi \& Zimmerbauer, 2011), are proved to be widely used by local administration in region's institutionalization and branding process (Šifta, 2016; Šifta \& Chromý, 2017). Three levels of a region, 'given', 'made' and 'perceived' (Semian, 2016) are traced here: local power bodies (councils, administrations) represent through graphic heraldic symbols their perceived idea of a region, and these symbols are entering everyday practices of other actors, including ordinary people.

However, not all historical regions are reproducing with equal success. While Volhynian, Podolian and Galician symbols are widely used in modern practice, Bratslavian and, especially, Kyivan heraldic symbols are much less common. Unfortunately, previous researches did not consider exactly these two historical regions, and therefore, it is impossible to conclude how universal such a pattern is, or the problem lies in the chosen identity markers (historical heraldry). It may be supposed that the presence of the central city name (Kyiv) in the name of the region (Kyivschyna) reduces the range of possible spatial interpretations, firmly binding perceptual region to the specific oblast (Kyivska). Also, special status of Kyiv as a city-region may create obstacles to the use of the heraldic symbol of the capital in the surrounding oblast. In case of Bratslavschyna, it seems that Podolian identity gradually displaces the Bratslavian one, as they are no more perceived as equal, but the second is subordinated to the first (second-level identity).

On the other hand, the results illustrate ongoing transformation of the territorial shape of regional identities. For example, Podolia has clearly 'retreated' in the south 
and southeast, but expanded to the north of Khmelnytska oblast, while Volhynia factually has 'lost' Zhytomyrska oblast. These patterns in general coincide with the patterns of people's regional consciousness (Melnychuk \& Gnatiuk, 2018) and the study of ergonyms derived from the names of historical regions (Gnatiuk \& Melnychuk, 2019). The biggest differences between the results obtained using different methods concern Ternopilska oblast (except for the extreme north): ergonyms point out the simultaneous presence of Galician and Podolian identities, and study of regional consciousness demonstrate self-identification of people with these two regions, while heraldic symbols indicate total absence of any identities of historical regions. However, this apparent contradiction may be not critical as both patterns indicate a refusal to unambiguously define the oblast's affiliation to one historical region.

Anterior conclusions (Gnatiuk \& Melnychuk, 2019; Marek, 2020b) suggest that the most ambiguous and fuzzy regional identity is observed in the administrative regions with (1) the most radical administrative changes in terms of boundary mismatches, where (2) none of identities of historical regions had initially dominated, and where (3) modern administrative centre is located near the phantom boundary between historical regions. This study generally confirmed these observations, as well as earlier proposed classification of modern Ukrainian administrative oblasts as 'anchor' or 'swing' (Gnatiuk \& Melnychuk, 2019). In particular, typical anchor oblasts are: (1) Vinnytska and Khmelnytska oblasts - strong Podolian identity, (2) Volynska oblast - strong Volhynian identity, (3) Lvivska and Ivano-Frankivska oblasts - strong Galician identity. On the other hand, Ternopilska and Zhytomyrska oblasts were confirmed to be swing: in both cases the oblast emblems point at belonging to several historical regions at the same time, and heraldry of historical regions is rarely used at the district level. Ambiguous situation is observed in Rivnenska oblast: while previous research classified it as swing (wavering between Volhynia and Polesia), the present one classifies it rather as an anchor oblast, strongly identified as a part of Volhynia. Probably, the situation is influenced by the hierarchical construction of the Ukrainian heraldic system: the emblems of districts often develop the main idea of the oblast emblem, and the emblem of Rivnenska oblast uses Volhynian heraldic symbols, which stipulates for their use at the level of districts. Anyhow, some difference between the two identity markers is quite expected as different action actors may define different spatial limits of the same (homonymous) region (Semian, 2012, 2016). With regard to Kyivska oblast, certain conclusions cannot be drawn due to aforementioned extremely rare use of historical heraldic symbols associated with Kyivschyna.

However, the use of historical heraldic symbols not only illustrates reproduction of historical regions and their identities, although in transformed spatial shapes, but also sometimes emphasizes differentiation between the modern oblasts, contributing to the development and strengthening of new regional identities. In particular, selective use of Galician heraldic symbols in Lviv and Ivano-Frankivsk oblasts (golden lion and black jackdaw respectively) depict the division of the Galician symbolic heritage between the modern regions. In this manner, it is impossible nowadays to speak about purely Galician symbols, as they become more and more oblast-specific. Besides, there is evidence that some principally new heraldic symbols of the modern Kyiv oblast are emerging, e.g. viburnum blossom appears on the emblems in 6 districts of Kyiv oblast as a regional symbol.

\section{Conclusions}

The use of heraldic symbols as a marker of identity of a region showed results similar to other methods. Nevertheless, observed differences may be explained by the hierarchical construction of the heraldic system and the involvement of different 
actors or, to be precise, their representations of the same region, in case of different markers - e.g. local power bodies in case of heraldic symbols, private businesses in case of ergonyms, and ordinary people in case of direct survey.

The study once again confirmed the validity of the theory considering a region as a social construct and a dynamic process. The identity of historical regions, which do not de jure exist on the map for almost a century, is reproduced as their symbols are actively used by modern administrative regions in the process of their own institutionalization, uniting the present and the past of a territory. On the other hand, the spatial shape of identity of historical regions has changed under the influence of new administrative boundaries. Contemporary informal regions share the names and basic graphic symbols with their original prototypes (historical regions), but differ from them in terms of spatial boundaries.

Although historical heraldic symbols are widely represented in contemporary territorial heraldry, their use depends on a particular region. In some cases (Kyivschyna, Bratslavschyna) too rare use of them suggests weakening of identity of respective historical region and hence its gradual disappearance. However, such conclusions cannot be drawn from the use of a single identity marker (e.g. heraldic symbols), as it was illustrated on the example of Ternopilska oblast. Some observations indicate that regional graphic symbols may change (as it is supposed for Kyivschy- na) or be divided between new administrative regions growing at the grounds of the same informal region, like symbolical heritage of Galicia has been divided between contemporary oblasts. The findings point out that for successful use in different modern administrative units (regions), symbols and a name of historical region should be universal (i.e. not tied to particular city or another small location).

In the context of the above, promising area of further research includes more detailed analysis of contemporary symbols in 'swing' administrative regions. Another yielding field is represented by graphic symbols of regions that have never been administrative units and thus never had own heraldic symbols (e.g. Polesia or Donbas in Ukraine). Unlike historically-rooted heraldry, such symbolic elements may be too vague for unambiguous definition; however, it is possible to solve this puzzle involving both statistical methods and in-depth case-studies. Investigation in these directions will shed more light on formation and reproduction of regions and further contribute to never-ending but unreservedly needed discussion on the conceptualization of region.

\section{Editors' note:}

Unless otherwise stated, the sources of tables and figures are the authors', on the basis of their own research.

\section{References}

Chalupa, J. (2015). Historickogeografická česko-moravská zemská hranice: rekonstrukce, percepce, významy. (Master's thesis). Praha: Charles University.

Chromý, P. (2003). Formování regionální identity: nezbytná součást geografických výzkumů. In V. Jančák, P. Chromý, M. Marada (Eds.), Geografie na cestách poznání (pp. 163-178). Praha: Charles University.

Chromý, P., Kučerová, S., Kučera, Z. (2009). Regional identity, contemporary and historical regions and the issue of relict borders - the case of Czechia. Regions and Regionalism, 9(2), 9-19.

Cresswell, T. (2013). Geographic thought. A critical introduction. Chichester: Wiley-Blackwell. 
Dobysh, M., Yatsenko, B. (2020). Borders, constituency politics, and "our man" voting in electoral geography of Ukraine. Belgeo, 2. https://doi.org/10.4000/belgeo.38851

Giddens, A. (1984). The Constitution of Society. Outline of the Theory of Structuration. Cambridge: Polity Press.

Gnatiuk, O. (2014). Nazvi pìdpriêmstv ta organìzacij Ukraïni âk marker teritorìal'noï ìdentičnostì naselennâ (The names of enterprises and organizations of Ukraine as a marker of the territorial identity). Kiïs'kij geografičnij ŝoričnik / Kyiv Geographical Almanac, 9, 67-77. [in Ukrainian]

Gnatiuk, O., Melnychuk, A. (2019). Identities with historical regions - are they adapting to modern administrative division? The case of Ukraine. European Spatial Research and Policy, 26(1), 175-194. https://doi.org/10.18778/1231-1952.26.1.09

Graham, B. (2000): The past in place: Historical geographies of identity. In B. Graham and C. Nash (Eds.), Modern historical geographies (pp. 70-99). Harlow: Pearson Education Limited.

Grechylo, A. (2000). Teritorial'ni simvoli Galic'ko-Volins'koï deržavi drugoï polovini XIII - počatku XIV stolit' (Territorial symbols of the Galicia-Volhynia State in the second half of the XIII - beginning of the XIV centuries). Zapiski Naukovogo tovaristva imeni Ševčenka / Notes of Shevchenko Scientific Society, 240, 255-263. [in Ukrainian]

Grechylo, A. (2004). Contemporary flags of the Ukrainian regions: Old traditions and new designs. In Proceedings of the XX International Congress of Vexillology. Stockholm, 27th July to 1st August 2003 (pp. 233-255). Bergen.

Grechylo, A. (2008). Sučasnì simvoli oblastej Ukraïni (Contemporary symbols of Ukrainian Regions. Kyiv-Lviv). [in Ukrainian]

Grechylo, A. (2010). Ukraïns'ka teritorial'na geral'dika (Ukrainian Territorial Heraldry). Lviv. [in Ukrainian] Homanyuk, M. (2016). Zatavrovanij Pivden': vid Gerodota do dekomunizaciï (The Tavria-marked South: From Herodotus to decommunization). Kritika, 1-2 (219-220), 2-7. [in Ukrainian]

Homanyuk, M. (2017). Panaceâ tavrii: toponim "Priâtnyj vo vseh otnošeniâh" (Tavria as a panacea: A toponym "pleasant in all respects"). Visnik Harkivs'kogo nacional'nogo universitetu imeni V.N. Karazina. Seriâ "Sociologični doslidžennâ sučasnogo suspil'stva: metodologiâ, teoriâ, metodi" / Visnyk of V. N. Karazin National University. Series "Sociological Studies of Contemporary Society: Methodology, Theory, Methods", 39, 209-214. [in Russian]

Homanyuk, M. (2019). "Battle for Tavria": A historical region in politics and in the market of goods and services. Ekonomichna ta Sotsialna Geografiya, 82, 20-26.

https://doi.org/10.17721/2413-7154/2019.82.20-26

Homanyuk, M. (2020). Vernakulârnye regiony i gosudarstvennye ideologii. Tavrijskij kejs (Vernacular regions and state ideologies: the Tavria case). Ideology and Politics Journal, 1(15): 12-32. https://doi.org/10.36169/2227-6068.2020.01.00002 [In Russian]

Jańczak, J. (2015). Phantom borders and electoral behavior in Poland historical legacies, political culture and their influence on contemporary politics. Erdkunde, 69(2), 125-137. https://doi.org/10.3112/erdkunde.2015.02.03

Kasala, K., Šifta, M. (2017). The region as a concept: traditional and constructivist view. AUC Geographica, 52(2), 111-121. https://doi.org/10.14712/23361980.2017.17

Kašková, M., Chromý, P. (2014). Regional product labelling as part of the region formation process. The case of Czechia. AUC Geographica, 49(2), 87-98. https://doi.org/10.14712/23361980.2014.18

Kolosov, V., Więckowski, M. (2018). Border changes in Central and Eastern Europe: An introduction. Geographica Polonica, 91(1), 5-16. https://doi.org/10.7163/GPol.0106

Kowalski, M. (1999). Electoral geography in Poland. In Spatial Research in Support of the European Integration (pp. 87-95). Pécs: Centre for Regional Studies. 
Kowalski, M. (2019). Spatial differences in voting behaviour among the inhabitants of rural areas in Eastern Europe. In J. Bański (Ed.), Three Decades of Transformation in the East-Central European Countryside (pp. 143-163). Cham: Springer. https://doi.org/10.1007/978-3-030-21237-7_7

Kowalski, M. (2020). The Early Mediaeval Slav-German border (Limes Sorabicus) in the light of research into Y-chromosome polymorphism in contemporary and historical German populations. Geographia Polonica, 93(4), 569-596. https://doi.org/10.7163/GPol.0190

Krykun, M. (1993). Administrativno-teritorial'nij ustrìj Pravoberežnoï Ukraïni v XV-XVIII st. Kordoni voêvodstv u svitli džerel (Administrative territorial division of the right-bank Ukraine in XV-XVIII Centuries. The boundaries of voivodeships in view of sources). Kyiv: MP Ofort. [in Ukrainian]

Kysliak, V., Neskoromnyi, O. (Eds.). (2010). Ukraïna: herby ta prapory (Ukraine: Coats of arms and flags). Kyiv: Parliamentary Publishing House. [in Ukrainian]

Lynch, K. (1960). The image of the city. Cambridge: MIT Press.

Marek, P. (2015). Vnímání reliktní hranice na př̌kladu severní části česko-moravské zemské hranice. (Master's thesis). Brno: Masaryk University.

Marek, P. (2020a). Region as a social construct and the critical discussion of the Paasi's conceptualization of regional identity. Geografie, 125(1), 47-68. https://doi.org/10.37040/geografie2020125010047

Marek, P. (2020b). Transformation of the identity of a region: Theory and the empirical case of the perceptual regions of Bohemia and Moravia, Czech Republic. Moravian Geographical Reports, 28(3), 154-169. https://doi.org/10.2478/mgr-2020-0012

Markeliuk, A., Homanyuk, M., Sarkisov, A. (2019). Kartografična ìnterpretaciâ danih sociologičnogo doslìdžennâ pri vivčennì social'noï percepciï prostoru (Cartographic interpretation of sociological data in the study of social perception of space). Naukovi zapiski Hersons'kogo viddilu Ukrains'kogo geografičnogo tovaristva / Scientific Notes of the Kherson Department of the Ukrainian Geographical Society, 11, 97-104. [in Ukrainian]

Melnychuk, A., Gnatiuk, O. (2018). Regional identity and the renewal of spatial administrative structures: The case of Podolia, Ukraine. Moravian Geographical Reports, 26(1), 42-54. https://doi.org/10.2478/mgr-2018-0004

Melnychuk, A., Gnatiuk, O., Rastvorova, M. (2014). Use of territorial identity markers in geographical researches. Scientific Annals of "Alexandru loan Cuza" University of lasi - Geography Series, 60(1), 157-184.

Mezentseva, N., Mezentsev, K. (2005). Percepcìnnì portreti regionìv Ukraïni (Perceptual portraits of Ukrainian regions). In Regional'ni problemi Ukraïni: geografičnij analiz ta pošuk šlâhiv virišsennâ (Regional problems of Ukraine: geographical analysis and search for solutions) (pp. 208-213). Kherson: PP Vyshemyrskyi. [in Ukrainian]

Neumann, I.B. (1994). A region-building approach to Northern Europe. Review of International Studies, 20(1), 53-74.

Nowak, K. (2018). The impact of the voivodeship boundaries on regional identity and perception of the Małopolska and Śląsk regions. Studia Regionalne i Lokalne, 1(71), 62-81.

https://doi.org/10.7366/1509499517104

Oliinyk, Ya., Gnatiuk, O. (2013). Metodičnì pìdhodi do doslidžennâ teritorìal'noï ìdentičnostì naselennâ (Methodical approaches to the study of population territorial identity). Ukraïns'kij Geografičnij žurnal ) Ukrainian Geographical Journal, 3, 34-40. [In Ukrainian]

Paasi, A. (1986). The institutionalization of regions: a theoretical framework for understanding the emergence of regions and the constitution of regional identity. Fennia, 164(1), 105-146.

Paasi, A. (1991). Deconstructing regions: notes on the scales of spatial life. Environment and Planning A, 23(2), 239-256. https://doi.org/10.1068/a230239

Paasi, A. (2001). Europe as a social process and discourse: considerations of place, boundaries and identity. European Urban and Regional Studies, 8(1), 7-28.

https://doi.org/10.1177/096977640100800102 
Paasi, A. (2002). Bounded spaces in the mobile world: deconstructing "regional identity". Tijdschrift voor Economische en Sociale Geografie, 93(2), 137-148. https://doi.org/10.1111/1467-9663.00190

Paasi, A. (2009). The resurgence of the "region" and "regional identity": theoretical perspectives and empirical observations on regional dynamics in Europe. Review of International Studies, 35(11), 121-146. https://doi.org/10.1017/S0260210509008456

Paasi, A. (2011). The region, identity, and power. Procedia - Social and Behavioral Sciences, 14, 9-16. https://doi.org/10.1016/j.sbspro.2011.03.011

Paasi, A., Metzger, J. (2017). Foregrounding the region. Regional Studies, 51(1), 19-30. https://doi.org/10.1080/00343404.2016.1239818

Paasi, A., Zimmerbauer, K. (2011). Theory and practice of the region: a contextual analysis of the transformation of Finnish regions. Treballs de la SCG, 71-72, 163-178.

Pred, A. (1984). Place as historically contingent process: Structuration and the time- geography of becoming places. Annals of the Association of American Geographers, 74(2), 279-297. https://doi.org/10.1111/j.1467-8306.1984.tb01453.x

Raagmaa, G. (2002). Regional identity in regional development and planning. European Planning Studies, 10(1), 55-76. https://doi.org/10.1080/09654310120099263

Reed, J.S., Kohls, J., Hanchette, C. (1990). The dissolution of Dixie and the changing shape of the South. Social Forces, 69(1), 221-233. https://doi.org/10.1093/sf/69.1.221

Rudenko, L., Paton, B. (Eds.). (2007). Nacional'nij Atlas Ukraïni (National Atlas of Ukraine). Kyiv: DNVP Kartohrafija. [In Ukrainian].

Semian, M. (2012). Searching for the territorial shape of a region in regional consciousness: The Český ráj (Bohemian Paradise), Czech Republic. Moravian Geographical Reports, 20(2), 25-35.

Semian, M. (2016). Region in its complexity: A discussion on constructivist approaches. AUC Geographica, 51(2), 179-188. https://doi.org/10.14712/23361980.2016.15

Semian, M., Chromý, P., Kučera, Z. (2016). Name as a regional brand: The case of local action groups in Czechia. Journal of Language and Politics, 15, 768-789. https://doi.org/10.1075/jlp.15.6.06sem

Šerý, M. (2014). The identification of residents with their region and the continuity of socio-historical development. Moravian Geographical Reports, 22, 53-64. https://doi.org/10.2478/mgr-2014-0018

Šerý, M., Šimáček, P. (2012). Perception of the historical border between Moravia and Silesia by residents of the Jeseník area as a partial aspect of their regional identity (Czech Republic). Moravian Geographical Reports, 20(2), 36-46.

Simon, C., Huigen, P., Groote, P. (2010). Analysing regional identities in the Netherlands. Tijdschrift voor Economische en Sociale Geografie, 101(4), 409-421. https://doi.org/10.1111/j.1467-9663.2009.00564.x

Siwek, T., Kaňok, J. (2000). Mapping Silesian identity in Czechia. Geografie, 105(2), 190-200.

Šifta, M. (2016). Graphic symbols and local identity: the case of use and perception of municipal emblems in the Liberec Region (Czechia). Geografisk Tidsskrift - Danish Journal of Geography, 116(2), 147-158. https://doi.org/10.1080/00167223.2016.1188021

Šifta, M., Chromý, P. (2017). The importance of symbols in the region formation process. Norsk Geografisk Tidsskrift - Norwegian Journal of Geography, 71(2), 98-113.

https://doi.org/10.1080/00291951.2017.1317285

UHS. (2020). Territorial symbols. Ukrainian Heraldry Society. [20 October 2020] http://uht.org.ua/en/part/terytot/

Vaishar, A., Zapletalová, J. (2016). Regional identities of Czech historical lands, Hungarian Geographical Bulletin, 65, 15-25. https://doi.org/10.15201/hungeobull.65.1.2

Vukosav, B. (2011). Geographic name Zagora and its reference to areas in the Dalmatian hinterland in the selected newspaper medium. Geoadria, 16(2), 261-281. https://doi.org/10.15291/geoadria.289 
Vukosav, B., Fuerst-Bjeliš, B. (2016). Labels of interest groups as indicators of a vernacular region: A case study in Croatia. Tijdschrift voor Economische en Sociale Geografie, 107(4), 454-467. https://doi.org/10.1111/tesg.12168

Więckowski, M. (2021). How border tripoints offer opportunities for transboundary tourism development. Tourism Geographies, https://doi.org/10.1080/14616688.2021.1878268

Zarycki, T. (1999). The persistence of the borders on the territory of Poland. In O. Brednikova, V. Voronkov (Eds.), Nomadic Borders (pp. 141-145). St. Petersburg: Centre for Independent Social Research. 53-57.

Zarycki, T. (2015). The electoral geography of Poland: Between stable spatial structures and their changing interpretations. Erdkunde, 69(2), 107-124. https://doi.org/10.3112/erdkunde.2015.02.02

Zelinsky, W. (1980). North America's vernacular regions. Annals of the Association of American Geographers, 70(1), 1-16. https://doi.org/10.1111/j.1467-8306.1980.tb01293.x

Zimmerbauer, K. (2011). From image to identity: Building regions by place promotion. European Planning Studies, 19(2), 243-260. https://doi.org/10.1080/09654313.2011.532667

Zimmerbauer, K., Paasi, A. (2013). When old and new regionalism collide: Deinstitutionalization of regions and resistance identity in municipality amalgamations. Journal of Rural Studies, 30, 31-40. https://doi.org/10.1016/j.jrurstud.2012.11.004

Zimmerbauer, K., Riukulehto, S., Suutari, T. (2017). Killing the regional Leviathan? Deinstitutionalization and stickiness of regions. International Journal of Urban and Regional Research, 41(4), 676-693. https://doi.org/10.1111/1468-2427.12547

Zimmerbauer, K., Suutari, T., Saartenoja, A. (2012). Resistance to the deinstitutionalization of a region. Borders, identity and activism in municipality merger. Geoforum, 43(6), 1065-1075.

https://doi.org/10.1016/j.geoforum.2012.06.009 